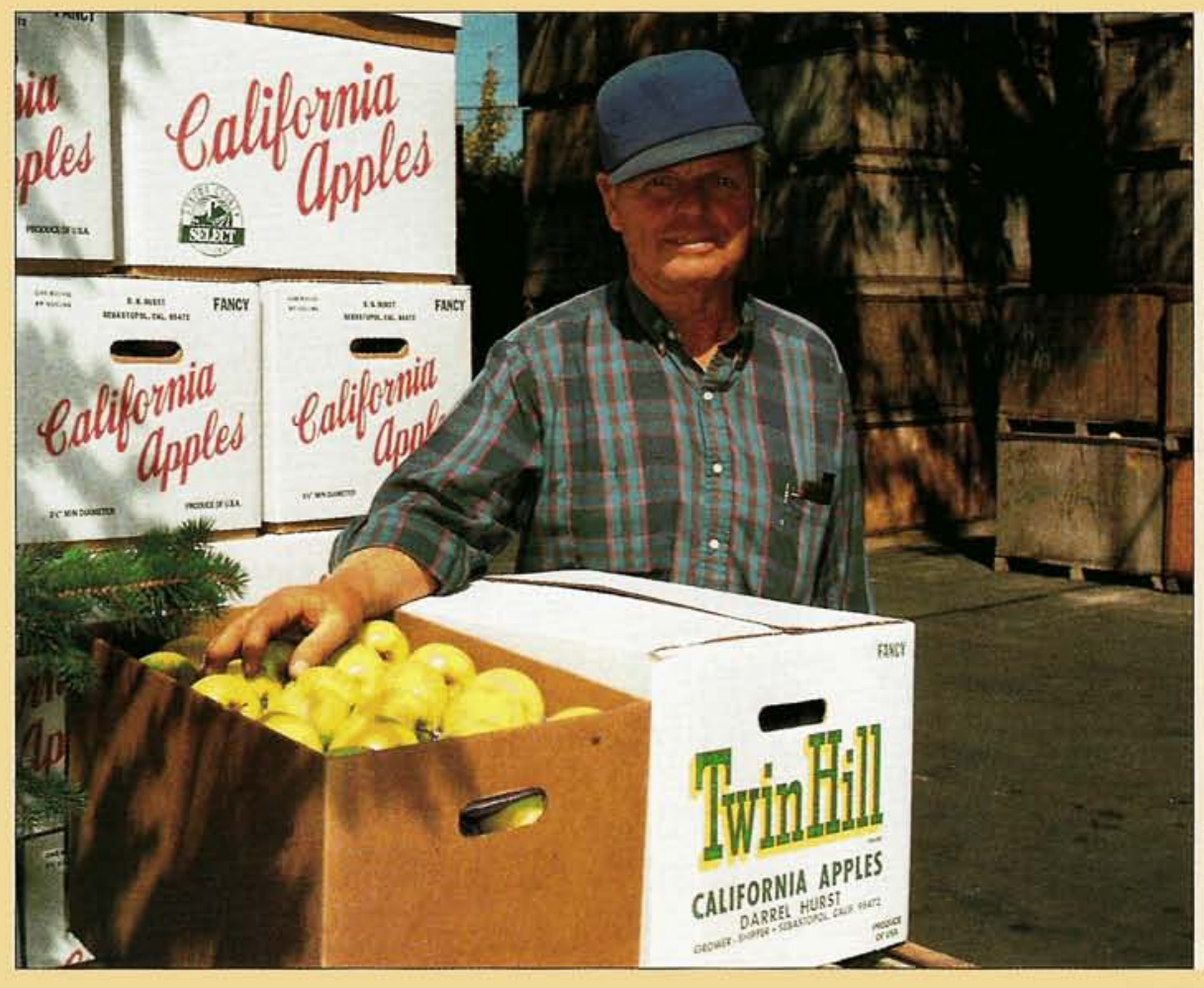

\section{Sonoma County farmers carve out new market niche}

$\mathrm{O}$ ne day, when Cindy Kozlowski was growing up on her family's Sonoma County farm, she painted the word "raspberries" on a sign and hung it out near the road.

Her billboard enticed a few motorists off the old Gravenstein Highway near Forestville but not nearly enough to use up all the berries the family was growing -400 to 500 flats a day. They also had to drive to San Francisco every day and to Los Angeles three times a week to sell at produce markets. Everything changed when Cindy's mother, Carmen, began making jam in the family kitchen.

Since that beginning,

Kozlowski Farms has evolved into a nationally known producer of gourmet jams, jellies, conserves, mustards, vinegars, syrups, sauces and salsas. Their roadside store, just past the farmhouse, has attractive displays and freshly baked pies, a picnic area and a soothing view of the 20 -acre farm.

"They're the epitome of a successful family farm," says Paul Vossen, a Sonoma County farm advisor. "The Kozlowskis have been successful for several reasons: They've diversified beyond the area's traditional apples, they've established a repu-
Above, Sonoma County Farm Advisor Paul Vossen designed a packing label for apple growers - just one effort to help small growers develop a marketing niche for their diverse agricultural products, ranging from Gravenstein apples and goat cheese to organic vegetables and wines.

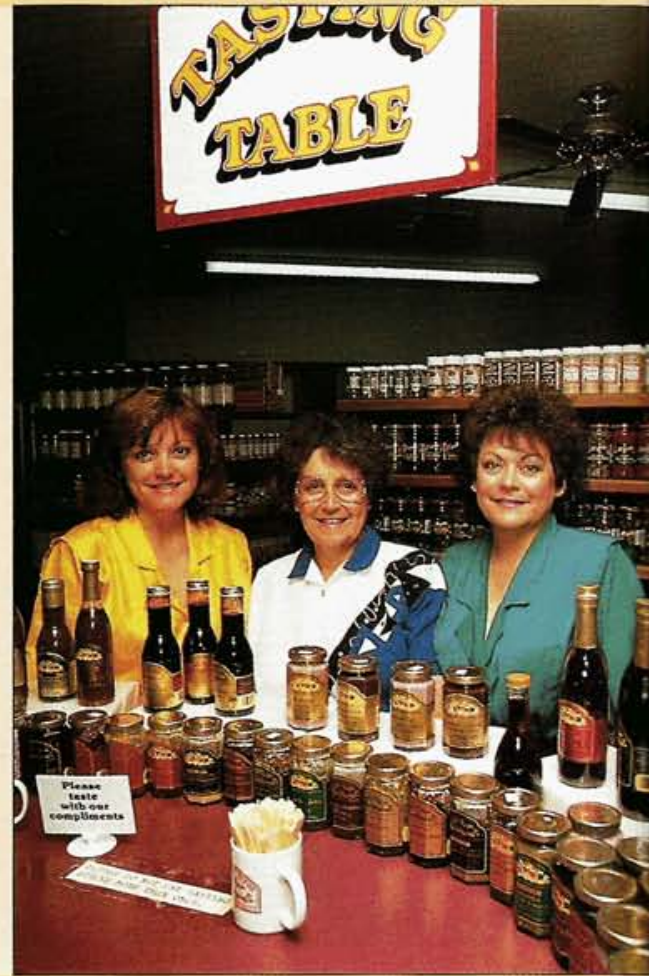

direct marketing: berries, tree fruits and nuts, fresh flowers, specialty vegetables, pumpkins and Christmas trees. Many of these products, marketed seasonally as fresh produce, can also be sold year-round as value-added products: jams and jellies, dried fruit, apple pies, wreathes and potpourri.

Several years ago, Vossen encouraged growers to join in marketing their products beyond the county line. "Gourmets nationwide have experienced our specialty produce, wines, seafood, meats and processed products," he says. "Yet many local farmers were unaware of the special attention they were getting."

Most producers were too small to develop their own marketing programs or to be represented by major commodity groups, grower associations and marketing orders. In 1987,

Vossen and other Cooperative Extension advisors invited innovative farmers, processors and marketers to explore coordinating their marketing efforts. "The response was outstanding," Vossen says.

The County Board of Supervisors appointed a 21-member special task force. The result was the Sonoma County Agricultural Marketing Program

(SCAMP). Vossen wrote in the Journal of Extension: "Bonds of trust replaced any initial resistance or mistrust. We brought together 21 people representing diverse agricultural commodities to promote our common link. And it worked." 
Far left, Sebastopol apple grower Darrel Hurst owns and operates one of the few remaining packing houses in Sonoma County. He and other growers who survived hard times in the industry learned to market their products directly to the consumer. Hurst's farm is one stop on a "Farm Trails" map of the region. (center) with daughters Starting in 1951 with a 20acre orchard of Gravenstein apples, the family diversified their business. Today they market Kozlowski Farms jams and jellies to visitors and mail-order customers nationwide.

Right, Farm Advisor raspberries from the Kozlowski farm.
Left, Carmen Kozlowski Cindy (left) and Carol. Vossen holds tray of

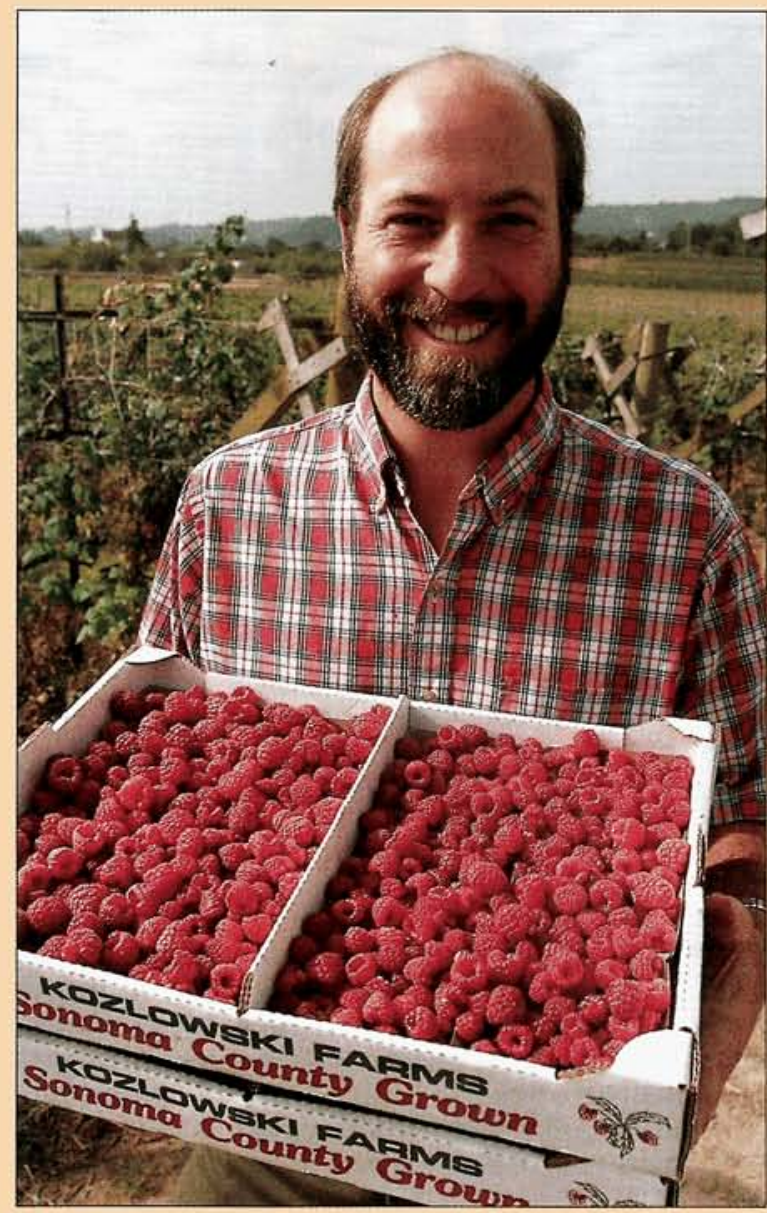

SCAMP membership has grown from 18 to 270-plus grower-processor and associate members, whose efforts have produced:

-The "Sonoma Select" logo to help consumers identify locally grown items.

- Seminars to help farmers evaluate their products, identify consumer demand, expand distribution, and learn communications skills.

- Booths at local fairs, farmers markets, in-store food tastings and other promotional events.

- Research into consumer attitudes about Sonoma County products.

- A marketing newsletter published for the agricultural community.

-Point-of-sale materials created for use in grocery stores.

- Employment of a merchandising salesperson to act as liaison between SCAMP members and markets.

- Promotional ads developed for radio, television, print media and billboards.

Historically, Sonoma County, especially Sebastopol, has always been known for its apples. Failure of the local cannery, competition from Washington state, escalating land values and urban encroachment have taken a toll on apple production. Once there were 25 packing houses near Sebastopol; now there are four.
Surviving growers formed the Sebastopol Apple Promotion Committee to boost sales and stabilize their industry, but they lacked a comprehensive marketing plan and were wasting money on ineffective promotions. Then a local supermarket advertisement for apples from "Apple Hill" in El Dorado County spurred them to action. "They got angry and said if they can do this, we can do it, too," Vossen says.

He helped growers focus on two objectives: getting local apples into local stores and getting them labeled as to Sonoma County origin. A newly hired marketing consultant and Vossen met with the five major supermarket chains in the area, and retail advertisements and point-of-purchase materials, such as recipe tear-offs, were established. The farm advisor also helped design a 7-by 11 -inch placard featuring two children admiring Sonoma County "farm-fresh" apples.

Vossen's emphasis on marketing is unusual; most farm advisors focus on production-related issues, but his involvement has reaped dividends for local apple growers and other small-scale Sonoma County growers. Produce buyers used to play one grower off another to get the lowest price, but for the last 5 years growers have seen fresh apple sales increase and prices stabilize.

-J. Stumbos

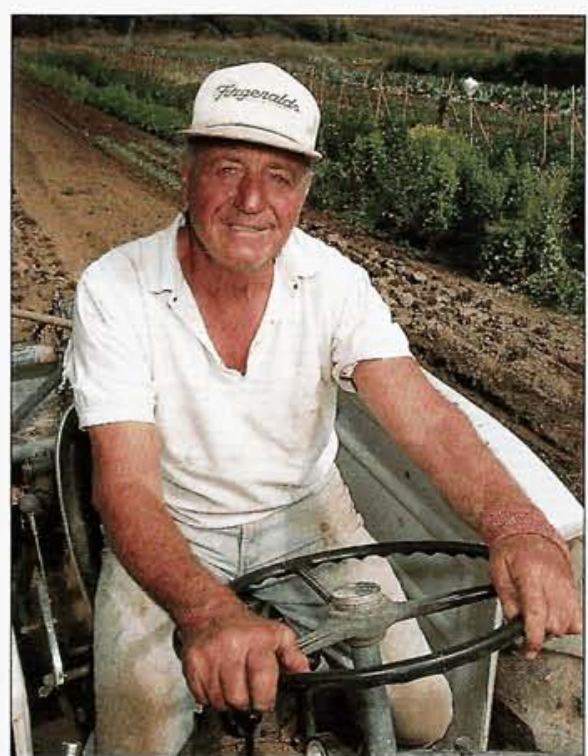

A relative newcomer to California, Antonio "Nino" LaScala cultivates Little Hill Farm in Sonoma County. "California is the place to grow vegetables," he says. "All you need is water!"

UC program (continued from p. 15) drying, processing and marketing them in an eye-catching way."

Cooperative Extension research and public service efforts benefit small farmers throughout the state. A glance at a recent Small Farm Program annual report describes:

- Stanislaus County Farm Advisor Jesus Valencia's "super sweet corn" variety field day.

- Contra Costa County Farm Advisor Janet Caprile's "creative cover crops" workshop.

-Extension Agricultural Engineer Jim Thompson's development of guidelines for low-cost, cold storage units.

-Yolo County Farm Advisor Gene Miyao's work on solarization for weed control.

-Extension Specialist Marita Cantwell's heat treatment to control postharvest pathogens of produce.

- Placer County Farm Advisor Garth Veercamp's Christmas tree irrigation study.

\section{The Small Farm Center}

While county-based advisors tailor research and Extension programs to meet local needs, the program's nucleus is the Small Farm Center at UC Davis. Established in 1980 with federal Rural Development Act funds, the center:

-Serves as a clearinghouse for questions from farmers, marketers, farm advisors, trade associations, government agencies and the academic community.

-Maintains a library of books, scientific and popular journals, reports, directories and periodicals covering production and marketing. 